\title{
ERRATUM
}

\section{Digging deep: how organisational culture affects care home residents' experiences - ERRATUM}

ANNE KILLETT, DIANE BURNS, FIONA KELLY, DAWN BROOKER, ALISON BOWES, JENNY LA FONTAINE, ISABELLE LATHAM, MICHAEL WILSON and MARTIN O'NEILL

doi: 10.1017/So144686X14001111, published online by Cambridge University Press 13 October 2014.

The affiliations for Dawn Booker, Alison Bowes and Isabelle Latham were listed incorrectly in this paper. The correct names and affiliations are listed below:

Dawn Booker, Association for Dementia Studies, University of Worcester. Alison Bowes, School of Applied Social Science, University of Stirling, UK. Isabelle Latham, Association for Dementia Studies, University of Worcester.

We apologise for this error.

\section{Reference}

Killett, A., Burns, D., Kelly, F., Brooker, D., Bowes, A., La Fontaine, J., Latham, I., Wilson, M. and O'Neill, M. Digging deep: how organisational culture affects care home residents' experiences. Ageing \& Society, published by Cambridge University Press, 13 October 2014, doi: 10.1017/So144686X14001111. 